\title{
Endangering humanity: an international crime?
}

Article

Accepted Version

McKinnon, C. (2017) Endangering humanity: an international crime? Canadian Journal of Philosophy, 47 (2-3). pp. 395-415. ISSN 1911-0820 doi:

https://doi.org/10.1080/00455091.2017.1280381 Available at https://centaur.reading.ac.uk/68692/

It is advisable to refer to the publisher's version if you intend to cite from the work. See Guidance on citing.

To link to this article DOI: http://dx.doi.org/10.1080/00455091.2017.1280381

Publisher: Taylor \& Francis

All outputs in CentAUR are protected by Intellectual Property Rights law, including copyright law. Copyright and IPR is retained by the creators or other copyright holders. Terms and conditions for use of this material are defined in the End User Agreement.

\section{www.reading.ac.uk/centaur}

\section{CentAUR}

Central Archive at the University of Reading

Reading's research outputs online 


\section{Endangering Humanity: An International Crime? \\ Catriona McKinnon \\ University of Reading, UK \\ c.mckinnon@rdg.ac.uk, +447843271903}

\section{Biographical note}

Catriona McKinnon is a Professor of Political Theory, and is Director of the

Leverhulme Doctoral Programme in Climate Justice, at the University of Reading. She is the author of Liberalism and the Defence of Political Constructivism (2002), Toleration: A Critical Introduction (2006), and Climate Change and Future Justice (2011). She is the (co)editor of The Demands of Citizenship (2000), The Culture of Toleration in Diverse Societies: Reasonable Tolerance (2003), Issues in Political Theory (2008, 2011, 2014), Climate Change and Liberal Priorities (2011), and The Ethics of Climate Governance (2015). She is presently writing a book defending the idea of a law of postericide, and an introductory book on climate justice.

\section{Acknowledgements}

This paper has benefitted from discussion with and comments from people at workshops at the Osgoode Hall Law School, York University (Toronto), the Future of Humanity Institute (University of Oxford), Centre for Ethics, Law and Public Affairs (Warwick University), The Arctic University of Norway (Tromso), Goethe University (Frankfurt), the School of Public Policy, University College London, and the Institute for Futures Studies (Stockholm). Comments and feedback from the following people in particular helped to improve the paper: Amanda Greene, Keith Hyams, Karim Jebari, Rob Jubb, Cecile Laborde, Nick Martin, Julia Mosquera, Tom Sorrell, Victor 
Tadros, Patrick Tomlin, Ed Page, Dominic Roser, and an anonymous referee for the journal. This work was supported by the Leverhulme Trust under Grant RF-2014-021.

\begin{abstract}
In the Anthropocene, human beings are capable of bringing about globally catastrophic outcomes that could damage conditions for present and future human life on Earth in unprecedented ways. This paper argues that the scale and severity of these dangers justifies a new international criminal offence of 'postericide' that would protect present and future people against wrongfully created dangers of near extinction. Postericide is committed by intentional or reckless systematic conduct that is fit to bring about near human extinction. The paper argues that a proper understanding of the moral imperatives embodied in international criminal law shows that it ought to be expanded to incorporate a new law of postericide.
\end{abstract}

Key words: Anthropocene, international criminal law, human extinction, human security, global catastrophe, intergenerational ethics. 


\section{Endangering Humanity: An International Crime?}

\section{Global Dangers in the Anthropocene}

We are living in the Anthropocene. This new epoch has been brought about by the scientific and technological advances made by our species since the Industrial Revolution. In the Anthropocene, people are capable of radically and irreversibly altering conditions on the planet in ways that seriously endanger all life on Earth, including that of Homo sapiens. The Anthropocene is an age of multiple global catastrophic dangers. Examples fall roughly into two categories. In the first, and better understood, category of 'environmental catastrophe' are global processes and outcomes that involve the degradation of the environment, where the mechanisms by which catastrophe could happen are known in virtue of sound theory and/or empirical evidence. In this category is global warming caused by anthropogenic greenhouse gas emissions and land use changes, a nuclear winter in the aftermath of nuclear war, and biological and chemical global warfare. In the second, and less well understood, category of 'technological catastrophe' are dangers for which we have far less empirical evidence and/or reliable theoretical knowledge. Examples here can involve nanotechnology, AI, synthetic biology, or experiments at facilities such as the Large Hadron Collider (LHC) going horribly wrong (Bostrom and Cirkovic 2011).

Many anthropogenic global catastrophes could impact on non-human life in disastrous ways. Damage to non-human life is still not commonly enough acknowledged in mainstream philosophical literatures about value in the Anthropocene, and nor are there widely practiced techniques of valuation that 
properly capture the nature and extent of such damage. That said, I shall only focus here on dangers to human beings that are created by conduct fit to cause anthropogenic global catastrophes. In particular, I shall defend in outline a new response to the danger of near human extinction that many global catastrophes could cause.

Despite the fact that the probability of total human extinction in the Anthropocene is likely to be low, human activity that could cause the species to go extinct is taken seriously as a danger by many experts (Hansen 2011; Rees 2003; Stern 2006; Matheny 2007; Posner 2004), ${ }^{1}$ for at least two reasons. First, human extinction, and points on the road to it, are taken to be extremely bad outcomes (Bostrom 2003; Auerbach 2015; Jamail 2015). ${ }^{2}$ And second, it is within our control (at least in theory) to address dangers of extinction with anthropogenic as opposed to non-anthropogenic causes, in large part because we are able to create these dangers through our own conduct: there is much we could do now to prevent global thermonuclear war, but little we can do now if an asteroid with Earth's name on it is hurtling at great speed towards us.

\footnotetext{
${ }^{1}$ For example, the Stern Review posited an extinction probability of 0.1 per cent per year which is equivalent to a 9.5 per cent risk of human extinction within the next 100 years (Stern 2006, 47). Subsequently, Stern commented, 'I got it wrong on climate change - it's far, far worse' (The Observer, 26 January 2013).

${ }^{2}$ I take it that danger on this scale is not on all fours with common-or-garden activities through which we impose reciprocal risk, such as driving a car, and that consequentialists and contractualists alike can have good grounds for condemning conduct creating global catastrophic dangers (Kumar 2005).
} 
It is important to be clear that the fact that we are not in a position to specify precisely by how much the probability of extinction is increased by any of our present activities is not a barrier to treating these activities as endangering extinction (Hansson 2011; Seth 2014). In general, we can often accurately judge an outcome to have been made more likely by some conduct without being able to specify the exact shift in probability that the conduct has brought about. Moreover, and following Henry Shue, I shall assume that when a case exhibits the following three key features we 'can reasonably, and indeed [we] ought to, ignore entirely questions of probability beyond a certain minimal level of likelihood' (Shue 2010: 147):

(1) massive loss: the magnitude of the possible losses is massive;

(2) threshold likelihood: the likelihood of the losses is significant, even if no precise probability can be specified, because (a) the mechanism by which the losses would occur is well understood, and (b) the conditions for the functioning of the mechanism are accumulating; and (3) non excessive costs: the costs of prevention are not excessive (a) in light of the magnitude of the possible losses and (b) even considering other important demands on our resources (Shue 2010).

As Shue rightly insists, it is possible to make accurate yet imprecise judgements that the probability of an outcome has been increased by a given conduct. Most cases of conduct fit to bring about near human extinction as a result of anthropogenic global catastrophe will have this character. One aim of this paper is to indicate the nature of the massive loss that would be instantiated in a state of near human extinction. Given that political institutions fit to govern such serious dangers must be well upstream of 
them, we have a mandate - indeed, an obligation - to address now the question of how to govern conduct fit to create a danger of near human extinction. In this paper I shall discuss the global and intergenerational damage to human security that is caused by any serious danger of near extinction. I shall argue that faulty conduct fit to significantly increase the likelihood of near human extinction beyond Shue's threshold lies within the scope of international criminal law qua system of moral ideals, and that this body of law ought to be extended to include a new criminal offence of 'postericide'. Postericide is committed by intentional or reckless conduct fit to bring about the near extinction of humanity.

I shall have nothing to say here about the costs of prevention pursued through international criminal law, expanded to include a new law of postericide. And neither shall I argue that conduct in any particular case exhibits all the features that would qualify it as postericidal. Nevertheless, and in order to fix thoughts, it will be helpful briefly to lay out two highly stylised and simplified examples of contexts in which postericidal conduct could be found.

First, consider the case of the Narcissistic President. A businessman with no political track record gets elected President of the United States. He has a professional track record of bankruptcy, sharp practice, racial discrimination and involvement with the mafia, and a personal track record of sexual assault and misogyny. He has an extremely narcissistic personality, exhibiting a grandiose sense of entitlement, a need for admiration, a lack of empathy, and pompous arrogance. He staffs the White House and his Cabinet with inexperienced people drawn from the private sector, many of whom hold obnoxious views. As he promised in his divisive and hate-filled campaign, he immediately asserts his intention to withdraw the U.S. from the Paris Agreement, which is the last slim hope humanity has to avert catastrophic climate 
change. His view is that climate change is a hoax perpetrated by the Chinese for economic advantage. He, and his advisors, are climate deniers who ignore scientific evidence (McKinnon 2016), including research published just after his election win showing that climate sensitivity may have been massively underestimated in previous IPCC Reports, with the consequence that temperature rises by 2100 under a 'business as usual' scenario are likely to be much higher than estimated hitherto: in the range of 4.78C to $7.36 \mathrm{C}$ rather than $2.6 \mathrm{C}$ to $4.8 \mathrm{C}$ (Friedrich et al 2016). As a consequence of the Narcisstic President's decision, China also withdraws from the Paris Agreement. The Agreement limps on but is emasculated and ineffective. The world heats up in line with the higher end estimates of climate sensitivity under a business as usual scenario, and our grandchildren find themselves in a catastrophic 7C world (Pearce 2007; Lynas 2008). ${ }^{3}$

Second, consider Unilateral Solar Radiation Management (SRM). SRM is a type of geoengineering. Following a prominent report by the Royal Society in 2009, geoengineering per se is commonly defined as 'the deliberate large-scale manipulation of the planetary environment to counteract anthropogenic climate change' (Shepherd et al 2009: 1). SRM techniques tackle the effects of greenhouse gas emissions by reducing the extent to which the Earth absorbs solar radiation, thus cooling the planet. There are a variety of SRM techniques on the table at present; probably the most discussed of these is stratospheric aerosol injection (SAI). SAI involves putting vast quantities of reflective particles (e.g. sulphur dioxide or specially designed nano particles) into the stratosphere, using fleets of planes, ships, or tethered balloons. Imagine that climate sensitivity is at the lower end of the range

\footnotetext{
3 This 'imagined' scenario was written before Donald Trump became President Elect of the U.S.A. The reality of his Presidency could, of course, be far worse than this scenario.
} 
for which we have recent evidence, and that our grandchildren find themselves in a $4 \mathrm{C}$ world under a business as usual scenario in 2100 , either as a result of the decisions of a long dead Narcissistic President, or of other failures of previous generations to mitigate effectively when they still had the time. As the world heated up throughout the twenty-first century, a concentrated research group of geoengineering scientists worked hard to develop a deployable SAI technology. Their work was heavily, but quietly, funded by the world's largest fossil fuel MNC, with a prescient eye on future profits and a willingness to take a punt on an unproven technology. The work fell between the cracks of domestic, regional and global governance structures, none of which were fit to handle it. ${ }^{4}$ By 2100 , in the face of dangerous climate change, the world's leaders are finally ready to divest from fossil fuels at speed, but need to buy time to make this happen. SAI technology is by now ready to deploy and the MNC (suitably compensated by states in need) rolls it out. Within a decade, global temperatures stabilise, and our grandchildren start to try to make the changes to fix the climate, knowing this will take centuries (perhaps longer) to work, if it works at all. The work begins, but within 50 years the biggest global financial crash the world has ever seen causes the collapse of the MNC, and SAI is abruptly terminated. In the SAI deployment period, and despite all the political will, divestment happened slowly: the pumping of greenhouse gases had barely slowed down throughout deployment. Atmospheric concentrations at the point of termination are so high that global temperatures sky rocket to $7 \mathrm{C}$ or upwards.

To emphasise, the point of these examples is not to make it obvious who is at fault in performing postericidal conduct, what the fault is, what damage is done fit for the

\footnotetext{
4 The governance of climate engineering is being addressed by a Report (jointly written by an Academic Working Group to which I belong) under the aegis of the Forum for Climate Engineering Assessment (http://www. http://ceassessment.org/), to be published in 2017.
} 
attention of international criminal law (although I shall discuss this below), or at what point Shue's threshold likelihood was passed in each case. All these points raise difficult questions that cannot be addressed in this paper (McKinnon: forthcoming 2018). Instead, the point is that in this phase of the Anthropocene we already have contexts in which postericidal conduct could happen. The stylised examples both relate to climate change. If climate change were to happen on the scales in the examples it would very likely cause the collapse of civilization as we know it and propel humanity into a state of near extinction (Oreskes 2013). We know that societies of the past have declined and disappeared (sometimes rapidly) as a result of having destroyed their own resource base while failing to see clearly that collapse was coming and/or by being paralysed with respect to averting it (Diamond 2005). Every case is complicated. However, if we think that the local collapses of the past could be replicated on a global scale, we should be thinking now about institutions fit to prevent these outcomes. Global catastrophic collapse could push the species to the brink of extinction: and climate related examples are far from the only ones available (Bostrom and Cirkovic 2011; Klein 2015).

In what follows I shall give an account of what counts as a state of near extinction and what is bad about such a state. I shall argue that intentional or reckless conduct creating a significant danger of near extinction falls within the scope of international criminal law, given our best theories of it as a system of moral ideals.

\section{What is near human extinction?}

To understand what is wrong with conduct creating a danger of near extinction we need to understand what is bad about a state of near extinction per se. But before 
broaching that we need to understand what states of affairs count as near human extinction.

There are at least two dimensions of nearness that are relevant to understanding near human extinction: proximity to a numerical threshold and proximity in time to an extinction event. A state of near human extinction is one that instantiates one, or both, of these properties insofar as they are sufficient for total human extinction. Taking each property in turn, near extinction could mean proximity to a numerical threshold of human beings below which Homo Sapiens could not continue to reproduce effectively. For example, if there is not sufficient genetic diversity in a small pool of potential procreators then it might not be possible to avoid widespread birth defects that would prevent further successful reproduction. However, there are cases in which the number of members per se in a human population would not matter for determining whether that population is near extinction. The universe could contain very few human beings without Homo Sapiens being in a state of near extinction, so long as the conditions in which those humans exist are fit to support reliable reproduction. Perhaps, in the future, benign AI could manage an artificial environment on Earth or elsewhere that could manipulate human procreation through genetic engineering, or some other technology, in a way that makes the idea of a numerical threshold redundant.

A different dimension of nearness to extinction is temporal. Homo Sapiens could be in a state of near extinction because the end is nigh: perhaps the LHC will tomorrow create a black hole that will simultaneously and instantaneously cause the death of every member of the species. In these types of case, numbers do not matter for nearness to extinction: in the LHC technological catastrophe there is no decline in numbers and Homo Sapiens goes extinct in the blink of an eye. Again, however, there 
are cases in which temporal proximity to a state of total extinction does not matter for nearness either. For millennia our ancestors numbering just a few thousand lived in east Africa before migrating across what is now the Red Sea between 90,000 to 130,000 years ago (Brahic 2012). Of all the populations of the genus Homo that coexisted with Homo Sapiens, there was no guarantee that our ancestors would survive, let alone expand and become dominant. With numbers of Homo Sapiens as low as 2000-5000, disease or environmental catastrophe could have easily wiped out this population (Zhivotovsky et al 2003). But this could have been the case without it being true that extinction was imminent throughout this period.

Finally, a state of near human extinction can be understood in terms of a combination of temporal and numerical factors; for example, when numbers of human beings are declining very fast in a way that will end in total extinction. What marks out all these types of cases is that a mechanism is in operation that has the power to propel Homo Sapiens out of existence entirely if it continues to operate. The mechanism could do this either by killing individuals (or small groups) sequentially until all are dead, or by culminating in an event that will make humans go extinct, or both.

What matters to establishing whether a state is one of near extinction is the mechanism by which the state is brought about and/or sustained. In the benign AI case there is a mechanism that will enable continued reproduction despite low numbers. And in the ancestors case, features of the conditions of life for early Homo Sapiens explain why their continued existence could have been precarious despite the fact that there was no imminent danger. The way in which to assess whether a state of near extinction exists is to consider whether mechanisms are operating in that state 
that are fit to quickly deplete the global population of human beings, or to kill them all in a short space of time. I shall call these 'extinction mechanisms'.

This way of understanding near human extinction gives insight into an important feature of conduct that creates a danger of near human extinction. This will be conduct that either creates a new extinction mechanism, exacerbates an existing extinction mechanism, or both.

\section{Is near extinction bad because total extinction is bad?}

Once we know what near human extinction is, we can ask what makes it bad. This matters because unless near human extinction is bad, there can be no case to make that conduct making near human extinction significantly more likely is wrongful in ways that lie within the purview of international criminal law. There are two ways of understanding the badness of near human extinction.

The first 'derivative' account has it that the badness of near extinction is derived from the badness of total extinction. This is an instance of a more general approach to the evaluation of risk which has it that badness of any risk is inherited from the badness of the outcome that will come to pass if the risk ripens. Hence: the reason why smoking is bad is that it could cause lung cancer. Any conduct that makes a bad outcome significantly more likely is ipso facto bad itself, all else being equal. ${ }^{5}$ Extinction mechanisms are those that could continue to operate to bring about total extinction, and ex hypothesi total extinction is made more likely by the operation of such mechanisms, so on this view we need to establish what would be bad about total human extinction in order to establish what is bad about near human extinction.

\footnotetext{
5 This is not beyond dispute. See Jarvis Thomson: 1986.
} 
There are at least three ways to argue for the badness of total human extinction, all of which are difficult to make convincing. Since my defence of a law of postericide does not depend on a derivative account of the badness of near extinction I shall not go into great detail here. Briefly, the three ways of argument and their challenges are as follows.

First, total extinction could be bad in a way that exhibits a 'final value' (Korsgaard 1983). ${ }^{6}$ A state of affairs (or fact, or object) has final value when it is valuable independent of the ways in which it is instrumental to, or otherwise related to, other valuable states of affairs. An argument that total human extinction would be bad in terms of final value would have to establish that the eternal continuation of Homo sapiens would be a good thing in itself, independent of it being good for people, other species, or anything else. Perhaps the best bet for making this case is an appeal to aesthetic value, but it remains a challenging view to defend.

The second type of value which could be exhibited by total human extinction as a bad outcome is instrumental value, which is a type of extrinsic value. Following Michael Zimmerman, '[t]hat which is extrinsically good [or bad] is good [or bad] not ... for its own sake, but for the sake of something else to which it is related in some way' (Zimmerman 2015: 32). Something is instrumentally valuable when it is a means to, or the cause of, a distinct valuable thing. To argue that total human extinction would be bad in a way that exhibits instrumental value would require specifying further distinct values which would be damaged by total human extinction. Derek Parfit argues (in part) in this way (Parfit 1986). He invites consideration of the comparative badness of three states: (1) peace, (2) a nuclear war that kills $99 \%$ of the world's existing population, and (3) a nuclear war that kills 100\%. Of these outcomes

\footnotetext{
${ }^{6}$ Korsgaard's discussion does not address extinction.
} 
he says, '(2) would be worse than (1), and (3) would be worse than (2). Which is the greater of these differences? Most people believe that the greater difference is between (1) and (2). I believe that the difference between (2) and (3) is very much greater' (Parfit 1986: 453). In support of this claim he appeals to the value of future human experiences, and progress in the fields of human knowledge - especially with respect to what he calls 'Non-Religious Ethics'.

Another type of extrinsic value which could be exhibited by total human extinction is inherent in the state insofar as it is related to other valuable things in ways that are not instrumental or causal (Zimmerman 2015: 33-4). Samuel Scheffler makes this type of argument for the badness of total human extinction (Scheffler: 2013). The argument is focused on what he calls 'the afterlife conjecture': the continuation of human life on Earth is a condition for any temporal cohort of people valuing their present projects, pursuits and activities. He asks us to imagine a 'doomsday scenario', wherein an asteroid is certain to collide with the Earth and destroy it completely 30 days after one's death (Scheffler 2013: 19). He reflects that it is plausible to think that we would react to a doomsday scenario by becoming emotionally detached from, demotivated to engage in, and deprived of reasons to continue with projects, pursuits and activities across the range of human life, from large-scale and explicitly future oriented projects (such as finding cure for cancer), to every day activities and pleasures. For Scheffler, valuing brings together doxastic, deliberative, attitudinal and dispositional states oriented towards the thing that is valued. By thinking through what a doomsday scenario would mean for our valuings understood in terms of these states, we can see that these valuings depend (noninstrumentally) on future people coming into existence after our own deaths. 
Although it is possible to give derivative account of the badness of near human extinction that appeals to the badness of total human extinction understood in terms of final, instrumental or inherent value, none of these approaches would clearly bring conduct creating a significant danger of near human extinction within the scope of international criminal law. The moral ideals at the heart of international criminal law are unlikely to be expansive enough to address (for example) conduct that brings about bad outcomes understood in aesthetic terms (final disvalue), a diminution of progress in the fields of human knowledge (instrumental disvalue), or damage to the conditions necessary for practices of valuing (inherent disvalue). Derivative accounts are all interesting, and some may be true, but they are irrelevant to establishing the need for a new law of postericide. The law of postericide does not aim to prevent human extinction per se, and the offence of postericide responds to the badness of near human extinction in virtue of the damage that would be done to people in this state, independent of whether this state is also bad in derivative ways.

\section{Near extinction and human security}

The right focus for justifying a law of postericide is on the badness of near extinction insofar as it involves damage to victims of a type already recognised in international criminal law. My central claim is that extinction mechanisms would cause damage to human security on a catastrophic massive scale, and thus that it is legitimate to criminalise faulty conduct that creates or exacerbates the operation of such mechanisms making total human extinction significantly more likely.

Conceptions of human security range along a scale from thin to thick. Thin security directs concern to protecting people from 'threats to life and limb' only (Sorrell 2013, 177). Thick security covers a variety of threats that go beyond threats 
to life and limb. The thick conception of security is evident in many landmark Reports. For example, the 1994 UN Human Development Report presents security as embodying a 'concern with human life and dignity' and is focused on the importance of 'safety from the constant threats of hunger, disease, crimes and repression' (UNDP 1994). ${ }^{7}$

Furthermore, human security is a temporally extended good: what matters for security is not just the goods to which people have access at any point in time but also whether that access will continue in a reliable way in the future. Being free from the threat of physical violence today is of minimal value to me in trying to live my life well unless I know that most of my tomorrows will be the same. What matters just as much about security is its trajectory. This brings the interests of people not-yet-born within the purview of political and social institutions that function well with respect to

${ }^{7}$ The Report identifies seven areas in which human security can be damaged:

1. Economic security, requiring 'an assured basic income'.

2. Food security, 'requiring physical and economic access to food'.

3. Health security, requiring freedom from disease and access to health services.

4. Environmental security, requiring protection of the environment and natural resources as a habitat for human beings.

5. Personal security, requiring freedom from violence inflicted by states, groups, and individuals.

6. Community security, requiring the protection of groups - family, ethnic, religious etc. - insofar as these groups do not perpetuate oppressive practices.

7. Political security, requiring the protection and creation of political societies that honour basic human rights (UNDP 1994, 25-33). 
security. Because extinction mechanisms continuously function to sustain a state's numerical or temporal nearness to total extinction, they not only create and/or sustain massive damage to human security in a given time slice, but also make it very likely that the damage will extend into the near future, and possibly longer: extinction mechanisms damage both the achievement and the trajectory of human security.

Presently existing human beings inhabit a Westphalian world. For us, extinction mechanisms could be those fit to destroy the infrastructure of states, and the international institutions that bind them together (insofar as they do) in peace. Human security is damaged by activity and conditions that affect persons' and communities' access to fundamental human goods. When states are just, or at least well-ordered, they are instrumental in ensuring human security for people within their borders. But states can also cause great damage to human security: the ideals of state security and human security do not always align (Rothschild 1995). Human security only contingently requires a Westphalian world order. If well ordered states are instrumental to human security then the arguments I make here also count as arguments for protecting the security of well ordered states, which means protecting their sovereignty.

What sort of good is human security? A first thought is that human security is a basic human right. For example, Henry Shue sometimes makes this claim. What he means by it is that human security a right without which no other rights can be enjoyed (Lazarus 2015; Shue 1996). For this to be true we must be able to identify the agents holding duties that correlate with the basic right to security (Lyons 1970). There are at least two options: individuals or collectives such as states.

If individuals hold duties that correlate with the rights that all people have to security (with a reliable trajectory) then we get some strange looking conclusions. 
Consider a scenario in which the mechanism of near extinction is the voluntary and uncoerced choices of individual people not to procreate. ${ }^{8}$ Imagine that people become convinced en masse by the teachings of the Voluntary Human Extinction Movement and that the majority of them simply stop procreating. ${ }^{9}$ In this scenario humanity moves to a state of near extinction within 100 years, and is sustained only by a few pockets of procreators who do not follow the VHEM. If individuals hold duties that correlate with people's rights to security, then it looks like we have to make the following claims about non-procreators.

First, we have to claim that non procreators have a duty to procreate that is generated by respect for people's security rights (Lazarus 2015; Waldron 2011, 2189). ${ }^{10}$ Freedom to choose not to procreate is a central liberty right on any account of it, in which case assigning a duty to non procreators to procreate in the name of respect for the basic right to security generates a serious clash of rights. Although rights can clash, and although procreation rights are not beyond question (McMahan 1981), we should try to avoid a moral infrastructure that has such a clash at its heart. Second, given that non procreators as well as procreators suffer damage to security as the cumulative result of their individual choices, the view implies that non procreators have self-regarding duties to procreate so as not to violate their own rights to security. It is deeply controversial to think that people have self-regarding duties, and even

8 Thanks to Helen Frowe for first suggesting this case to me.

${ }^{9}$ The VHEM are a real movement. See http://www.vhemt.org/.

${ }^{10}$ This requirement would be an extreme example of what Waldron calls the potential 'voraciousness' of the ideal of security; that is, how the pursuit of security could 'skew the balance between security and other important rights in damaging ways', Waldron (2011, 218-9; Lazarus 2015, 439). 
more controversial to think that these duties are generated by rights they have against themselves. This is another reason to reject the claim that non procreators violate people's rights to security in the voluntary extinction scenario.

The root of the problem with assigning to non procreators responsibility for mass violations of the basic right to security is that this approach treats security an as individualised good which is degraded by attacks - or the risk of them - on particular individuals that would violate their right to security. As Waldron notes in commentary on Henry Shue, it is preferable to use a public good model for thinking about security. As he puts it, '[I]individuals benefit from security (in the enjoyment of their rights) not because their own particular security is attended to on a focused one-by-one basis but because threats to security in general are removed or reduced by less personalized means' (Waldron 2011, 213). It is debatable whether individuals can have rights to public goods (MaCormick 1994; Raz 2000; Reaume 1988). If human security is conceived of as the object of a basic right, however, this claim that has to be defended. If this claim cannot be defended then we can conceive of the massive global and intergenerational insecurity that characterises near extinction scenarios as bad because it is (as Waldron puts it) indispensable for the enjoyment of human rights, basic and beyond (Waldron 2011).

Creating a danger of near extinction is not the only way in which human security can be damaged on a global and intergenerational scale. For example, a tyrannical world government, or desperate inequality between small elites and the mass of the world's poor with respect to survival goods, could also cause such damage. The relationship between a state of near extinction and human security shares the structure of the relationships between other, more familiar, endangerments. For example, that all people have a right to life explains why causing anyone's death 
through drunk driving, medical negligence, or use of a firearm is bad. Or: that all people have a right to freedom of conscience explains why it is bad to punish anyone for apostasy, or to indoctrinate into a religious creed. When we judge a state of affairs to be bad we do so by reference to underlying values which also justify such judgements of different states of affairs. In the Anthropocene we are, in an unprecedented way, capable of bringing about a state of near extinction through our own conduct. That other states of affairs could be bad because of the damage done to human security in them does not mean we are not justified in treating the state of near extinction as a distinct case.

The examples just given of causing death by drunk driving, medical negligence, punishment for apostasy etc. all involve wrongful conduct. With an account of the badness of near extinction in hand we can ask whether there could be wrongful conduct fit to create a danger of near extinction. Obviously, there is conduct fit to create this danger; arguably, this is what defines the Anthropocene. For example, the danger we could be in of catastrophic climate change is ultimately an effect of human greenhouse gas emissions, created by the conduct of people from around 1750 until the present day. This conduct is not wrongful, at least insofar as it is performed by ordinary people going about their daily lives. However, there are other types of agents, both individual and collective, whose influence in the world marks them off from ordinary people, and renders them capable of wrongful conduct that could create a danger of near human extinction. I outlined two such cases in the Introduction. Those who think these cases are at too great a distance from reality, or are the only cases of their type in the Anthropocene, will resist the need for a new law of postericide. Assuming (without argument here) that this resistance rests on a blurry vision of the world we are in, I shall make the case that wrongful conduct creating a 
danger of near extinction is properly addressed by international criminal law once it is justifiably expanded to include a new law of postericide.

\section{The Criminal Offence of Postericide}

International criminal law should be extended to include a new law that criminalises wrongful conduct creating a serious danger of near extinction. I call this a law of postericide. Postericide is committed by:

Intentional or reckless conduct fit to bring about the near extinction of humanity.

The actus reus for postericide is conduct of a type fit to create a new, or exacerbate an existing, extinction mechanism. It is likely that such conduct could only be undertaken in a systematic way by group agents such as MNCs or states. Because trials under international criminal law assign criminal liability only to individuals, principles are required that justify the attribution of criminal responsibility to individuals for the postericidal conduct of groups to which they are appropriately related. This is the case for nearly all prosecutions under international criminal law: postericide is not unusual in this respect. Where the actus reus for postericide differs from existing offences is that it specifies the creation of a danger as part of the crime. Although the offence of torture gives precedent in international criminal law for offences that relate to conduct independent of the outcome brought about by the conduct, there is no precedent for crimes of endangerment such as postericide. This is not the case in domestic jurisdictions, where 'inchoate' offences of risk imposition are common; for example, drunk driving, or the sale of hazardous products. 
Criminal acts under a law of postericide are akin to that of drunk driving or dangerous driving. The prosecution of an act as an inchoate criminal offence does not depend on showing that the act itself has causal powers fit to impose the danger; all that is required is showing that the act is a token of the relevant type. With respect to drunk driving, the type will be 'driving with a blood alcohol content over n', where n is set by looking at evidence that shows the incidence of death caused by driving by people with various levels of blood alcohol content, and by judgements about what counts as an acceptable level of risk. With respect to postericide, the type will be conduct which creates a new, or exacerbates an existing, extinction mechanism. Criminalisation of this type of conduct is justified only against the background of an argument that extinction mechanisms cause unacceptable damage that is (or ought to be) addressed by international criminal law. I argued in the previous section that the value of human security (with a reliable trajectory) should figure heavily in an account of this damage.

The mens rea for postericide - the subjective element of the crime that relates to the agent's mental states - is intention or recklessness. When an agent acts with the purpose of imposing an impermissible danger on a victim, they act for wrongful reasons and attack their victim. When an agent acts recklessly they fail to be guided by the right reasons in their conduct imposing an impermissible danger, despite being conscious of the impermissibility of the danger and the reasons not to impose it on others. Agents acting in this way endanger their victims (Duff 2005). In assessing whether an agent is guilty of attacking a victim by acting with a particular purpose we need to know the reasons for which the agent did in fact act. In assessing whether an agent is guilty of endangering a victim by acting recklessly we need to know the reasons to which they ought to have attended in forming their intention to act. 
All offences under international criminal law as it presently exists have intention as a mens rea. However many domestic jurisdictions specify recklessness as a mens rea for some criminal offences; for example, carrying a concealed weapon (in the US). Furthermore, in some domestic jurisdictions recklessness is a mens rea for inchoate crimes; for example, in the UK a person can be guilty of attempted rape if they are reckless with respect to the victim's lack of consent, all else being equal (Duff 1995). An implication of my argument for postericide as an inchoate offence that qualifies as an attack or as an endangerment is that there are some cases in which international criminal law should have more continuity with domestic criminal law.

There are many conceptual difficulties in the very idea of an offence of postericide and there is no hope of working through them in a paper of this length (McKinnon: 2018). In particular, I shall say nothing further about the agency necessary for postericidal conduct, or its mens rea. Instead, I shall focus on why there is a strong case for thinking that international criminal law ought to be expanded to include this new offence.

\section{Postericide as an offence under international criminal law}

The moral odiousness of postericidal conduct makes it fit to 'deeply shock the conscience of humanity' for the reasons related to human security laid out earlier (Rome Statute 2002). But the case is deeper than that: our best existing normative theories of international criminal law provide principled theoretical reasons for incorporating a new offence of postericide into that body of law. I shall outline two persuasive theories of the international criminal law as a normative system in order to show that a law of postericide has a proper place in international criminal law. These 
theories focus on human rights, and on the universal norms that bind together the community of humanity. ${ }^{11}$

First, consider the idea that international criminal law is morally justified as an institution fit to protect basic human rights. There are at least two forms of this approach which have different levels of commitment to the 'collective' element of international crimes; that is, the extent to which conduct violating basic rights must victimise people as members of a group, or be perpetrated by a group, in order to fall within the scope of international criminal law. In order of decreasing commitment to the collective element these approaches are:

1. that international criminal law protects people from group based violations of their basic human rights, where these violations also harm humanity as a whole;

2. that international criminal law protects people as individuals from basic rights violations, where the violations are caused by the widespread and systematic conduct of groups; $;^{12}$

${ }^{11}$ A third approach, not discussed here, is David Luban's account of international criminal law as an instrument for making good the failures of states to perform the functions according to which they are justified (Luban: 2004).

12 There is also a third version of the human rights approach that rejects the collective element as a necessary condition for criminalisation under international criminal law (Renzo, 2012). Because this approach does not deny that crimes with a collective element are the business of international criminal law it does not challenge my arguments that postericide ought to be supported by theories of international criminal law that focus on human rights, and insist on a collective element. 
Larry May’s analysis of crimes against humanity draws on (1). May identifies two singly necessary and jointly sufficient conditions for conduct to qualify as a crime against humanity. First, that the 'Security Principle' is not met; second, that the 'International Harm Principle’ is violated. The Security Principle expresses norms related to states' obligations to uphold the physical security and subsistence of their individual members. When states fail to do this their sovereignty may legitimately be pierced by international criminal law (May 2005). The Security Principle relates to obligations that states have to their members with respect to their basic human rights (e.g. their rights to liberty, or to be free from severe economic deprivation fit to deprive them entirely of subsistence). Although states may be under an obligation to respect the whole range of their members human rights (e.g. rights to political participation, cultural rights, or rights to equal pay for equal work), May argues that the violation of those rights does not justify legal intervention by the international community. For this reason, May calls his Security Principle 'morally minimalist' (i.e. thin).

The International Harm Principle states conditions for the criminalisation of conduct that satisfies the Security Principle. This is that the conduct must be group based insofar as victims are attacked because of their "non-individualised characteristics', and must cause serious harm (as specified by the Security Principle, i.e. serious violations of basic rights perpetrated by a state or other collective entity) (May 2005 83). May thinks that the International Harm Principle enables him to claim that an attack on an individual qua member (say) of an ethnic group by (say) a state constitutes 'an attack on humanity itself' $(2005,121)$. In support of this, he draws an analogy between humanity as a group susceptible to harm and clubs. Just as a club has interests in its members not being harmed (because this could damage the 
reputation of the club, or even threaten its existence) so humanity as a group has interests, inter alia in individual human beings not being harmed.

Prima facie May's analysis lends support to making postericide an offence under international criminal law. Part of what it is for states to uphold their citizens' basic rights is for them to uphold the conditions under which those rights are secure. Conduct creating a serious danger of near extinction damages this type of security on a global and intergenerational scale. When states (as collective agents) fail to protect their members from such insecurity, and/or when other collective agents create such insecurity, international criminal law is authorised to pierce state sovereignty.

This, though, is too quick. May requires that conduct lying in the scope of international criminal law harms humanity as a group in virtue of violating people's basic rights (or, I claim, threatening security, which is indispensable for these rights) in response to their 'non-individualised characteristics'. On May's view not all individual rights violations count as harm to humanity as a group. Only those rights violations that happen in virtue of an individual's membership of a group smaller than that of humanity as a whole (for example, when an individual is persecuted because they are a member of an ethnic or religious group) make the rights violation harmful to humanity as a whole. ${ }^{13}$ But conduct creating a danger of near extinction appears not to satisfy this requirement: the conduct affects people insofar as they are human, but not insofar as they are of a particular gender, religion, or nationality. On May's account postericide lies outside the scope of international criminal law because its victims are not group-based.

\footnotetext{
${ }^{13}$ May admits there could be exceptions, and gives the bombing of Hiroshima as an example $(2005,87)$.
} 
This part of May's account is a weak link and the fact that it would put postericide outside the realm of international criminal law does not impugn my argument. The key is May's claim that rights violations count as harm to humanity as a group only when they are 'individuality-denying' $(2005,86)$ insofar as victimhood depends on having qualities that could not have been autonomously chosen by the victim $(2005,85)$. One problem with this claim is that it is not clear why only some violations of basic human rights count as attacks that deny the individuality of victims. Assuming that no one would (or could?) autonomously choose to have their basic human rights violated why doesn't every such attack deny the individuality of the person attacked by making them a member of a group to which they would autonomously choose not to belong, i.e. the group of victims? In which case, does appeal to the interests of humanity as a group add anything (beyond rhetoric) to the argument that international criminal law ought to address conduct that is individuality-denying? As Altman and Wellman put it with respect to the Nazi crimes against Jewish people, '[h]arm was done to the humanity of the Jewish victims, but that is not to say that harm was done to humanity itself' $(2004,42)$.

The idea that international crimes cause harm to humanity as a group and that this can only happen as a result of individuality-denying attacks on people ought to be excised from May's approach. The fact that conduct creating a danger of near extinction does not fit with these weakest parts of May's overall approach is thus no criticism. But why would May appeal to the idea of harm to humanity given its obvious weaknesses? Altman and Wellman locate this appeal in the need to justify universal jurisdiction by appeal to a harm - such as a harm to humanity as a group that crosses borders. On their view, this takes the Westphalian paradigm too seriously and delivers an overly conservative vision of the scope of international criminal law. 
Instead, they think, conceiving of the moral heart of international criminal law in terms of protection for basic human rights makes it unnecessary to show the border crossing nature of offences to bring them within its scope.

Altman and Wellman's alternative model for thinking about the limits of state sovereignty under international criminal law draws on a parent-child analogy. Just as parents owe it to their children to treat them in certain ways, so states owe their citizens basic political and social goods - inter alia, basic human rights. And just as we think it is legitimate for external agencies to interfere with parents who are failing to treat their children in morally required ways so we ought to think it is legitimate for international criminal law to pierce the sovereignty of states failing to protect and respect the basic human rights of citizens. And 'a state adequately protects basic rights when it neither perpetrates nor permits widespread or systematic violations of those rights' $(2004,47)$. Altman and Wellman have it that what makes international crimes heinous is the individual rights violations they involve; they do not appeal to the idea of harm to humanity as a group. But they do retain some commitment to the collective element of international criminal law because they think that rights violations have to be widespread, and will often be systematic, to qualify as international crimes. $^{14}$

Taking Altman and Wellman's more sophisticated approach to international criminal law as a system for protecting basic human rights generates support for the

14 They deny that systematicity is strictly necessary: failed states do not act systematically and can commit international crimes (Altman and Wellman 2004, 489). Here, there is a further contrast with May, who makes systematic conduct (by states or state-like organisations) a necessary condition for criminalization in his ‘ideal model' of international criminal law (May 2005, 89). 
incorporation of postericide into this body of law. The danger of near extinction severely undermines the security of basic rights for all human beings affected by it, and is thus widespread. And conduct fit to create dangers of this magnitude and severity will very likely be systematic even in cases where just one person performs the act that ignites the danger.

The second theory of international criminal law that supports a new law of postericide focuses on the connection between this body of law and the fundamental human values that often appear in justification of its special features. A good way into this is to consider what trials do under international criminal law. The institutions of international criminal law are decentralised and weak; the trials they enable are not steps on the road to world government. Instead, this approach has it, these trials are expressive processes: they state a commitment to the moral impermissibility of a variety of acts performed ‘under colour of policy’ (Luban 2004 95). Trials under international criminal law express the moral horror of the human community at the conduct they address and courts conducting trials under universal jurisdiction have standing to do this insofar as they give voice to such moral outrage.

This approach criminal law per se is best developed in the work of Antony Duff. He thinks that criminal liability is a form of accountability to a particular political community given the public wrong of crime and in the absence (sometimes, even regardless) of an excuse or justification. Duff conceives of moral responsibility per se as relational in a triadic way: a person is always responsible as something (X), for something (Y), to someone or some body (Z). For Duff, moral responsibility (not) to do $\mathrm{P}$ is generated by roles that a person occupies; that is, by the normatively laden description under which she acts at any point in time. Those roles influence to whom she is answerable if she fails to do (or does) P (Duff 2009). Criminal responsibility 
attaches to people insofar as they are citizens of a particular political community. People sharing political community are answerable to one another as citizens for the commission of acts prohibited by principles of social cooperation making possible their shared political life (Duff 2009, 49). Such 'public' wrongs are crimes and those who perform them are criminally liable on grounds of fault when they lack justification or excuse. On this view, criminal law is declarative or communicative: '[i]ts role is not to make wrong what was not already wrong, but to declare that these pre-legal wrongs are public wrongs: to declare, that is, not merely that they are wrongs $[\ldots]$ but that they are wrongs that properly concern the whole polity, which should call their perpetrators to public account through the criminal courts' (2009, 86).

The expressive approach to criminal law extends to the international context (Duff 2009, 54-5). In this context we are accountable to one another not as members of a particular polity but as human beings qua political animals. When states or other agents damage conditions necessary for human beings to live together peacefully and profitably they are brought within the scope of international criminal law. Given how human security is indispensable for people to live decent lives whatever specific roles and associated duties they might have within particular polities, the expressive approach supports the extension of international criminal law to postericide.

It is worth noting that Duff's approach allows for a justification of a law of postericide because it captures both what present people owe to future people, and what they owe to one another in their future-regarding conduct. Using Duff's schema for accountability to generate an intergenerational account of the wrong of postericide: present people are accountable as members of the human political community, for conduct creating a danger of near extinction, to future people qua co- 
members of the political community of humanity. On this reading, postericide is an intergenerational crime. A second, intragenerational reading is that conduct creating a serious danger of near extinction violates obligations that bind together people in the same temporal cohort. Part of what it means to owe justice to one another is to secure and preserve just institutions for future people: when we fail to do this we do an injustice to other human beings existing right now (McKinnon: 2011). Using Duff's schema: present people are accountable as members of the human political community, for conduct creating a danger of near extinction, to present people qua co-members of the political community of humanity. On this reading, postericide is an intragenerational crime.

\section{Conclusion}

My aim here has been to show that the new dangers of the Anthropocene have the potential to cause massive global and intergenerational damage to human security, and that at least one response we are justified in taking seriously is the extension of international criminal law to a new a offence of postericide, all else being equal. It is obvious that there is much that must be made equal before the argument is fully complete and convincing. For example, I have said next to nothing about what type of agency is necessary for postericide, fault-based liability, excuses fit to defeat liability, how groups can be agents of postericide, how postericidal dangers are individuated, punishment for postericide, or the range of real world cases to which a law of postericide might apply. Even if these aspects of a law of postericide can be successfully defended in theory it remains an open question whether postericide ought to be incorporated into international criminal law as it presently exists. In particular, if this would be likely to make international criminal law even more fragile then there 
may be good strategic reasons for not pushing for reform. Similarly, if the advent of an international criminal offence of postericide would prompt those (largely very rich and powerful people) engaged in postericidal conduct to go to great lengths to hide what they are doing, thereby making the danger of near extinction more serious than it would have been without the law, then there is an argument for the status quo.

Nevertheless a good moral argument at the level of principle for postericide as a new international crime raises a question hitherto unasked in international legal theory and practice: why not?

\section{References}

Alkire, Sabina. 2003. 'A Conceptual Framework for Human Security'. Centre for Research on Inequality, Human Security and Ethnicity, University of Oxford, Working Paper 2.

Altman, Andrew and Wellman, Christopher Heath. 2004. 'A Defense of International Criminal Law'. Ethics, 115(1): 35-67.

Anderson, Kevin. 2015. 'Duality in Climate Science'. Nature Geoscience, advance online.

Auerbach, David. 2015. 'A Child Born Today May Live to See Humanity’s End Unless ...' http://blogs.reuters.com/great-debate/2015/06/18/a-child-born-today-maylive-to-see-humanitys-end-unless/ (accessed 17 July 2015).

Baum, Seth. 2014. 'The Great Downside Dilemma for Risky Emerging Technologies'. Physica Scripta 89: 1-10.

Beyin, Amanuel. 2011. 'Upper Pleistocene Human Dispersals out of Africa: A Review of the Current State of the Debate". International Journal of Evolutionary Biology, 1-17. 
Bostrom, Nick. 2002. 'Existential Risks'. Journal of Evolution and Technology 9. http://www.jetpress.org/volume9/risks.html (accessed 9 July 2015).

Bostrom, Nick. 2003. 'Astronomical Waste: The Opportunity Cost of Delayed Technological Development'. Utilitas 15 (3): 308-14.

Bostrom Nick and Cirkovic, Milan eds. 2011. Global Catastrophic Risks. Oxford: Oxford University Press.

Bostrom, Nick. 2013. 'Existential Risk Prevention as Global Priority'. Global Policy 4(1): $15-31$.

Brahic, Catherine. 2012. 'Our True Dawn'. New Scientist, 24 November 34-7.

Commission on Human Security, 2003. Human Security Now. New York:

Commission on Human Security.

Diamond, Jared. 2005. Collapse: How Societies Choose to Fail or Survive. London: Penguin.

Duff, Anthony. 1995. 'Recklessness in Attempts (Again)'. Oxford Journal of Legal Studies 15(2), 309-25.

Duff, Anthony. 2005. 'Criminalizing Endangerment'. In R.A. Duff and Stuart Green, Defining Crime: Essays on the Special Part of the Criminal Law. Oxford: Oxford University Press.

Duff, Anthony. 2009. 'Authority and Responsibility in International Criminal Law'. In Samantha Besson and John Tasioulas, The Philosophy of International Law. Oxford: Oxford University Press, 23-36.

Gardiner, Stephen, Caney, Simon, Jamieson, Dale and Shue, Henry, eds. 2010. Climate Ethics: Essential Readings. Oxford: Oxford University Press.

Friedrich, Tobias, Timmerman, Axel, Tigchelaar, Michelle, Timm, Oliver Elison and 
Ganopolsk, Andrey. 2016. 'Nonlinear climate sensitivity and its implications for future greenhouse warming'. Science Advances 2 (09 November): 1-11.

Geden, Oliver. 2015. 'Climate Advisers Must Maintain Integrity’. Nature 521 (7 May 2015): 27-28.

Hansen, James. 2011. Storms of My Grandchildren. London: Bloomsbury Paperbacks.

Hansson, Sven Ove. 2011. 'Coping With the Unpredictable Effects of Future Technologies'. Philosophy and Technology 24(2): 137-49.

Jamail, Dahr. 2015. 'Mass Extinction: It's The End of the World As We Know It'. http://www.alternet.org/environment/mass-extinction-its-end-world-we-know-it (accessed 17 July 2015).

James, P.D. 1992. The Children Of Men. London: Faber and Faber.

Jarvis Thomson, Judith. 1986. 'Imposing Risks'. In Judith Jarvis Thomson, Rights, Restitution, and Risk: Essays in Moral Theory. Cambridge, Mass.: Harvard University Press.

Klein, Naomi. 2015. This Changes Everything. London: Penguin. Korsgaard Christine. 1983. 'Two Distinctions In Goodness'. The Philosophical Review, XCII(2): 169-95.

Kutz, Christopher. 2000. Complicity: Ethics and Law for a Collective Age.

Cambridge: Cambridge University Press.

Lazarus, Liora. 2015. 'The Right To Security'. In Rowan Cruft, S. Matthew Liao and Massimo Renzo, Philosophical Foundations of Human Rights. Oxford: Oxford University Press, 423-441.

Lenman, James. 2002. 'On Becoming Extinct'. Pacific Philosophical Quarterly 83: 253-269. 
List, Christian and Pettit, Philip. 2011. Group Agency: The Possibility, Design and Status of Corporate Agents. Oxford: Oxford University Press.

Luban, David. 2004. 'A Theory of Crimes Against Humanity'. Yale Journal of International Law, 29: 86-168.

Lynas, Mark. 2008. Six Degrees: Our Future on a Hotter Planet. Harper Perennial. Lyons, David. 1970. 'The Correlativity of Rights and Duties'. Nous 4(1): 45-55. MacCormick, Neil. 1984. 'Taking the 'Rights Thesis' Seriously'. In Neil MacCormick, Legal Right and Social Democracy: Essays in Legal and Political Philosophy. Oxford: Clarendon Press, 126-153.

Matheny, Jason. 2007. 'Reducing the risk of human extinction'. Risk Analysis, 27(5):1335-44.

May, Larry. 2005. Crimes Against Humanity: A Normative Account. Cambridge:

Cambridge University Press.

McKinnon, forthcoming. 2018. Endangering Humanity: An International Crime.

Routledge.

McKinnon, Catriona. 2016. 'Should We Tolerate Climate Denial?. Midwest Studies in Philosophy, XL: 205-216.

McKinnon, Catriona. 2011. Climate Change and Future Justice: Precaution, Compensation, and Triage. London: Routledge.

McMahan, Jeff. 1981. 'Problems of Population Theory'. Ethics 92(1), 96-127.

Oreskes Naomi and Conway, Erik M. 2012. Merchants of Doubt: How a Handful Of Scientists Obscured the Truth on Issues from Tobacco Smoke to Global Warming.

London: Bloomsbury Press.

Oreskes, Naomi. 2013. 'The Collapse of Western Civilisation: A View From the Future'. Daedalus 142: 40-58. 
Parfit, Derek. 1986. Reasons and Persons. Oxford: Oxford University Press.

Pearce, Fred. 2007. With Speed and Violence: Why Scientists Fear Tipping Points in

Climate Change. Boston: Beacon Press.

Posner, Richard. 2004. Catastrophe: Risk and Response. Oxford: Oxford University Press.

Raz, Joseph. 2000. 'Right-Based Moralities'. In Marilyn Friedman, Larry May, Kate Parsons and Jennifer Stiff, Rights and Reason: Essays in Honour of Carl Wellman. Netherlands: Springer, 177-196.

Reaume, Denise. 1988. 'Individuals, Groups and Rights to Public Goods'. The University of Toronto Law Journal 38(1): 1-27.

Rees, Martin. 2003. Our Final Century. London: Arrow Books, 2003.

Renzo, Massimo. 2012. 'Crimes Against Humanity and the Limits of International Criminal Law'. Law and Philosophy 31(4): 443-476.

Rothschild, Emma. 1995. 'What is Security?'. Daedalus 124(3): 53-98.

Scheffler, Samuel. 2013. Death and the Afterlife. Oxford: Oxford University Press. Shepherd, John, Caldeira, Ken, Cox, Peter, Haigh, Joanna, Keith, David, Launder, Brian, Mace, Georgina, MacKerron, Gordon, Pyle, John, Rayner, Steve, Redgwell, Catherine, Watson, Andrew. 2009. Geoengineering the Climate: Science,

Governance, and Uncertainty. The Royal Society.

Shue, Henry. 1996. Basic Rights: Subsistence, Affluence, and U.S. Foreign Policy. Second edition. Princeton, N.J.: Princeton University Press.

Shue, Henry. 2010. 'Deadly Delays, Saving Opportunities'. In Climate Ethics: Essential Readings, edited by Stephen M. Gardiner, Simon Caney, Dale Jamieson and Henry Shue. Oxford: Oxford University Press. 
Sorell, Tom. 2013. Emergencies and Politics. Cambridge: Cambridge University Press.

Stern, Nicholas. 2006. The Stern Review: The Economics of Climate Change. UK Treasury.

United Nations Development Programme. 1994. Human Development Report 1994.

New York: Oxford University Press.

Von Hirsch, Andrew. 2012. 'Extending the Harm Principle: 'Remote' Harms and Fair Imputation'. In A.P. Simester and A.T.H. Smith, Harm and Culpability. Oxford: Oxford University Press.

Waldron, Jeremy. 2011. 'Security as a Basic Right (After 9/11)'. In Charles R. Beitz and Robert E. Goodin, Global Basic Rights. Oxford: Oxford University Press, 210-26. Zhivotovsky, Lev, Rosenberg, Noah, Feldman, Marcus. 2003. 'Features of Evolution and Expansion of Modern Humans, Inferred from Genomewide Microsatellite Markers'. American Journal of Human Genetics 72(5), 1171-86.

Zimmerman, Michael J. 2015. 'Intrinsic vs. Extrinsic Value'. The Stanford Encyclopedia of Philosophy. Edward N. Zalta (ed.), URL = <https://plato.stanford.edu/archives/spr2015/entries/value-intrinsic-extrinsic/> 